\title{
Boron, carbon, and oxygen isotopic composition of brachiopod shells: Intra-shell variability, controls, and potential as a paleo-pH recorder
}

\author{
Donald E. Penman ${ }^{a}, b, *$, Bärbel Hönisch ${ }^{a}$, E. Troy Rasbury ${ }^{c}$, N. Gary Hemming ${ }^{d}$, Howard J. Spero ${ }^{\text {e }}$ \\ a Department of Earth and Environmental Sciences and Lamont-Doherty Earth Observatory of Columbia University, Palisades, NY, 10964-8000, USA \\ ${ }^{\mathrm{b}}$ Department of Earth and Planetary Science, University of California at Santa Cruz, Santa Cruz, CA, 95064, USA \\ c Department of Geosciences, State University of New York at Stony Brook, Stony Brook, NY, 11794, USA \\ d School of Earth and Environmental Sciences, Queen College, Flushing, NY, 11367-1597, USA \\ e Department of Geology, University of California Davis, Davis, California, 95616, USA
}

\section{A R T I C L E I N F O}

\section{Article history}

Received 27 April 2012

Received in revised form 26 November 2012

Accepted 29 November 2012

Available online 7 December 2012

Editor: U. Brand

\section{Keywords:}

Boron isotopes

Brachiopod

Stable isotopes

Seawater $\mathrm{pH}$

\begin{abstract}
A B S T R A C T
The boron isotopic composition of biogenic carbonates has been used to reconstruct seawater $\mathrm{pH}$ and atmospheric $\mathrm{pCO}_{2}$ on Pleistocene and Cenozoic timescales. Because of their excellent preservation and extensive fossil record throughout the Phanerozoic, brachiopods are a promising candidate for extending the boron isotope record as far back as the Cambrian. Here we present stable carbon, oxygen, and boron isotopic measurements of modern Terebratulid brachiopod calcite in comparison with environmental pH estimates calculated from oceanographic data. Geochemical transects along the length and depth of single shells confirm previously published trends in carbon and oxygen isotopic composition. In the outer surface (primary and outermost secondary layers), $\delta^{11} \mathrm{~B}$ covaries with $\delta^{13} \mathrm{C}$ and $\delta^{18} \mathrm{O}$, with more negative values in the outer and more positive values in the middle of the shell. However, $\delta^{11} \mathrm{~B}$ deviates from $\delta^{13} \mathrm{C}$ and $\delta^{18} \mathrm{O}$ in the inner part of the secondary layer, where the $\delta^{13} \mathrm{C}$ and $\delta^{18} \mathrm{O}$ values are more positive and near equilibrium, whereas $\delta^{11} \mathrm{~B}$ returns to more negative values. A comparison of different specimens of the species Terebratalia transversa (Sowerby, 1846) and Laqueus californianus (Küster, 1844) microsampled from the middle part of the fibrous secondary layer demonstrates a clear correlation to ambient $\mathrm{pH}$ with a sensitivity similar to other empirical calibration curves for cultured planktic foraminifers, corals, and inorganic calcite. The relationship in other species is less clear and significantly offset, necessitating the use of a single species or a cross-calibration method with other species in paleo-pH reconstructions.
\end{abstract}

(c) 2012 Elsevier B.V. All rights reserved.

\section{Introduction}

The geochemistry of biogenic marine calcite records a wealth of information about the environmental properties of the fluid from which it precipitated. Whereas the primary fluid is seawater, organisms can modify the chemistry of the local environment at the site of calcification, necessitating careful study of species-specific effects and other controls on shell geochemistry. Articulate brachiopods primarily construct their shells of low-Mg calcite, which is a relatively stable form of $\mathrm{CaCO}_{3}$ compared to aragonite and high-Mg calcite (Berner, 1975). Because of this, brachiopod fossils are useful as archives for $\delta^{13} \mathrm{C}, \delta^{18} \mathrm{O}$, and ${ }^{87} \mathrm{Sr} /{ }^{86} \mathrm{Sr}$ (Compston, 1960; Lepzelter et al., 1983; Popp et al., 1986; Carpenter and Lohmann, 1995; Grossman et al., 1996; Brand et al., 2003; Korte et al., 2003, 2005; Grossman et al., 2008; Korte et al., 2008; Angiolini et al., 2012). A few studies have examined the potential for using boron isotopes in brachiopod shells as a $\mathrm{pH}$ proxy (Lécuyer et al., 2002; Joachimski et al., 2005), but a systematic examination of variations within brachiopod shells and between different

\footnotetext{
* Corresponding author.

E-mail address: dpenman@ucsc.edu (D.E. Penman).
}

species has not been published. An important first step towards testing the potential for boron isotopes in brachiopod shells to record seawater conditions is to examine how modern brachiopods record $\delta^{11} \mathrm{~B}$ from known conditions.

Dissolved boron is found in the ocean in two dominant forms: as charged borate ion $\left(\mathrm{B}(\mathrm{OH})_{4}^{-}\right)$and neutral boric acid $\left(\mathrm{B}(\mathrm{OH})_{3}\right)$. There is an equilibrium isotopic fractionation between the two species, with ${ }^{10} \mathrm{~B}$ preferentially incorporated into $\mathrm{B}(\mathrm{OH})_{4}^{-}$and ${ }^{11} \mathrm{~B}$ preferentially incorporated into $\mathrm{B}(\mathrm{OH})_{3}$ (Klochko et al., 2006). Because the relative abundance of those two species of dissolved boron in seawater is a function of $\mathrm{pH}$, the isotopic composition of both aqueous species must also change with $\mathrm{pH}$, towards more positive values as $\mathrm{pH}$ increases. Based on this relationship and shown by measurements of synthetic calcite from pH-controlled solutions (Sanyal et al., 2000), it is clear that $\mathrm{B}(\mathrm{OH})_{4}^{-}$is the dominant species incorporated during the precipitation of calcium carbonates from seawater (Hemming and Hanson, 1992). This means that measurements of boron isotopes in fossil marine calcite can provide a proxy for $\mathrm{pH}$ in ancient oceans, a crucial parameter for calculating the state of the marine carbonate system and atmospheric $\mathrm{CO}_{2}$ concentrations (Zeebe and Wolf-Gladrow, 2001). 
Boron isotope-based paleo-pH records from foraminiferal calcite have been used to produce $\mathrm{pCO}_{2}$ reconstructions on glacial-interglacial (Hönisch and Hemming, 2005; Hönisch et al., 2009) and Cenozoic (Pearson and Palmer, 2000) timescales. The boron-isotope proxy has been calibrated using two species of planktic foraminifers (Sanyal et al., 1996, 2001), benthic foraminifera (Rae et al., 2011), corals (Hönisch et al., 2004; Reynaud et al., 2004; Krief et al., 2010; Trotter et al., 2011), and inorganic calcite (Sanyal et al., 2000). However, foraminifer-bearing deep sea sediments are limited to the past 180 million years, so extended application of this marine proxy to the earlier part of the Phanerozoic, when carbon cycle models (Berner and Kothavala, 2001) and proxy data (Royer et al., 2004) suggest atmospheric $\mathrm{CO}_{2}$ variability an order of magnitude greater than present levels, must rely on a different fossil archive. Articulate brachiopod shells are found in marine sedimentary deposits from the Late Cambrian to the present,.They maintain a low Mg-calcite mineralogy (unlike mollusks or corals which often secrete aragonite, high-Mg calcite, or mixed mineralogy), and they have received extensive study as potential recorders of strontium, oxygen and carbon stable isotopes (Popp et al., 1986; Curry and Fallick, 2002; Auclair et al., 2003; Brand et al., 2003; Korte et al., 2005; Parkinson et al., 2005; Yamamoto et al., 2010; Brand et al., 2011).

Little is known about the controls and possible vital effects on boron isotopes in brachiopod shells. Systematic intra-shell variability up to 7\% was observed in $\delta^{13} \mathrm{C}$ and $\delta^{18} \mathrm{O}$ (Buening and Spero, 1996; Auclair et al., 2003), and has been interpreted to be either the result of kinetic isotope fractionation effects (Carpenter and Lohmann, 1995; Auclair et al., 2003), or a record of environmental change (Buening and Spero, 1996). Boron isotope data from various modern species of brachiopods exhibit a large (15-23\%) range (Hemming and Hanson, 1992; Lécuyer et al., 2002; Joachimski et al., 2005; Simon et al., 2006), which is too great to be attributed solely to regional $\mathrm{pH}$ variations. In this contribution, we explore intra-shell variation, species-specific effects and the potential for organic contamination on the boron isotopic composition of modern and fossil brachiopod shells.

Numerous studies have found species-specific differences in $\delta^{11} \mathrm{~B}$ of foraminifers, corals, and synthetic calcite grown at similar $\mathrm{pH}$ (Sanyal et al., 1996; Sanyal et al., 2000; Sanyal et al., 2001; Hönisch and Hemming, 2004; Reynaud et al., 2004; Foster, 2008; Hönisch et al., 2008), necessitating careful calibration of the proxy for each species through culture experiments or measurement of specimens from varying $\mathrm{pH}$ conditions. However, calibrations of natural samples from different ocean environments are hindered by the a relatively small $\mathrm{pH}$ variation in the typically narrow growth range of most organisms, and its covariance with other oceanographic parameters, notably temperature and nutrient concentrations. Brachiopods, on the other hand, can tolerate a wide range of depth, temperature, and pH conditions, allowing study of the respective effects of each of these parameters. However, brachiopod shell morphology is more complex compared to e.g. foraminifer shells, and includes layers of calcite fibers and organic proteins (Williams, 1966, 1968; Williams et al., 1997; Schmahl et al., 2004; Greisshaber et al., 2007; Goetz et al., 2009). The presence of organic components dispersed throughout the brachiopod shell provides further analytical challenges because it could cause isobaric interferences during Negative Thermal Ionization Mass Spectrometer (NTIMS) analysis, possibly resulting in anomalously negative $\delta^{11} \mathrm{~B}$ values (Hemming and Hanson, 1992). This study investigates the controls on the boron isotopic composition of brachiopod shell calcite by NTIMS analysis of $\delta^{11} \mathrm{~B}$ in combination with $\delta^{13} \mathrm{C}$ and $\delta^{18} \mathrm{O}$ measurements of modern specimens, in order to evaluate and calibrate the boron isotope-pH proxy for brachiopods.

\section{Materials and methods}

Modern brachiopod shells were provided by the American Museum of Natural History in New York. Catalogue numbers along with information

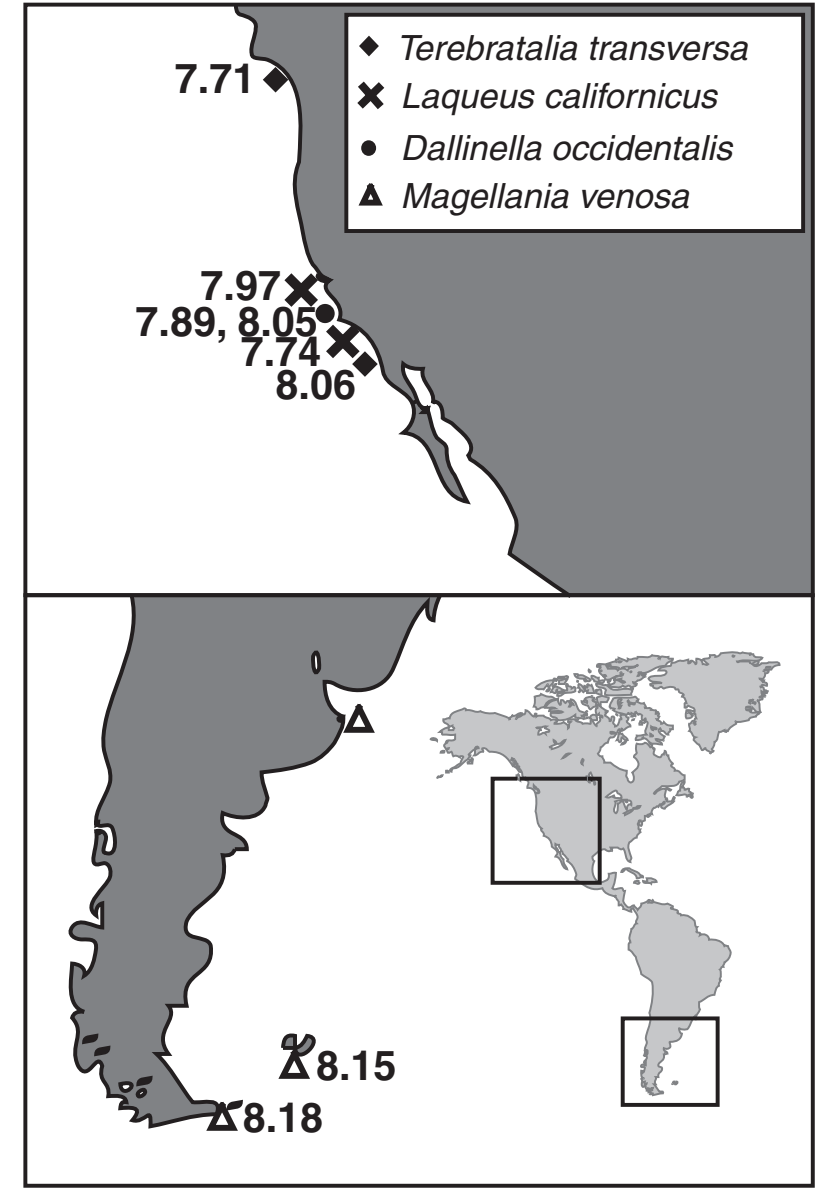

Fig. 1. Locations and environmental pH (seawater scale) of modern brachiopods used in this study.

on the location and depth of collection are listed in Table 1. Eight specimens were analyzed from 4 different species: Terebretalia transversa (Sowerby, 1846), Magellania venosa (Solander, 1789), Laqueus californicus (junior synonym of Laqueus californianus, Küster, 1844), and Dallinella occidentalis Fig. 1 (Dall, 1871). The ventral valves of all specimens were cut lengthwise (along their axis of symmetry, perpendicular to the hinge - see Fig. 2) using an Isomet saw, then mounted to a glass slide with epoxy and cut again to produce a $\sim 2 \mathrm{~mm}$ thick section. Sections were polished with $50 \mu \mathrm{m}$ grit on a polishing wheel and $\sim 1 \mathrm{mg}$ of $\mathrm{CaCO}_{3}$ was collected using a $0.5 \mathrm{~mm}$ dental burr. Two specimens, AMNH-unkA1 (T. transversa off of San Pedro, CA) and AMNH-unkA3 (M. venosa from Mar del Plata, Argentina), were microsampled along transects through the thickness of the shell and along the length of the shell for boron, carbon, and oxygen isotope analysis. Locations of sampling transects performed are shown in Fig. 2. As a consequence of the observed isotope patterns, all other specimens were sampled approximately halfway along their length and halfway through their width for B-isotope analysis.

To prevent isobaric interference from organic matter contamination during NTIMS analysis, two methods of removing organics were employed. All samples for B-isotope analysis were bleached overnight in $\mathrm{NaOCl}$ to remove organic material and subsequently rinsed and ultrasonicated 10 times in quartz-distilled water. In addition, several samples were oven-roasted in air at $375{ }^{\circ} \mathrm{C}$ for 24 hours prior to bleaching in $\mathrm{NaOCl}$. After drying, samples were dissolved in quartz distilled $2 \mathrm{~N}$ hydrochloric acid at a concentration of $30 \mu \mathrm{l}$ per mg of sample. $1 \mu$ l-aliquots of sample solution $(\sim 1 \mathrm{ng}$ of B) were loaded on degassed zone refined rhenium filaments with $1 \mu \mathrm{l}$ of boron free seawater (BFSW), which was prepared with 
Table 1

Brachiopod specimens used in this study. $\mathrm{pH}$ values on the seawater scale. $\delta^{11} \mathrm{~B}$ values are the most positive measured for each specimen.

\begin{tabular}{|c|c|c|c|c|c|c|c|c|c|c|c|}
\hline Catalogue \# & Species & Location & $\begin{array}{l}\text { Depth } \\
(\mathrm{m})\end{array}$ & $\begin{array}{l}\mathrm{T} \\
\left({ }^{\circ} \mathrm{C}\right)\end{array}$ & $\begin{array}{l}\mathrm{S} \\
(\%)\end{array}$ & $\begin{array}{l}\text { DIC } \\
(\mu \mathrm{mol} / \mathrm{kg})\end{array}$ & $\begin{array}{l}\text { TA } \\
(\mu \mathrm{mol} \text { eq. } / \mathrm{kg})\end{array}$ & $\begin{array}{l}\mathrm{pH} \\
\text { (SW scale) }\end{array}$ & $\delta^{11} \mathrm{~B}$ & $+/-$ & Source \\
\hline AMNH-unkA1 & Terebratalia transversa & $\begin{array}{l}33^{\circ} 42^{\prime} \mathrm{N} 118^{\circ} 16^{\prime} \mathrm{W} \\
\text { (San Pedro, CA) }\end{array}$ & 5 & 18.6 & 33.3 & NA & 2319 & 8.06 & 18.9 & 0.38 & Berelson, 1985 \\
\hline AMNH-499 & Terebratalia transversa & $\begin{array}{l}47^{\circ} 16^{\prime} \mathrm{N} 122^{\circ} 33^{\prime} \mathrm{W} \\
\text { (The Narrows, Tacoma, WA) }\end{array}$ & 5 & 7.7 & 29.56 & 2003.7 & 2038.7 & 7.71 & 16.6 & 0.27 & $\begin{array}{l}\text { Simone Alin (NOAA) } \\
\text { personal communication }\end{array}$ \\
\hline AMNH-unkA3 & Laqueus californicus & $\begin{array}{l}33^{\circ} 26^{\prime} \mathrm{N} 118^{\circ} 29^{\prime} \mathrm{W} \\
(\text { Catalina Island, CA) }\end{array}$ & 64 & 11.7 & 33.6 & 2051 & 2205.7 & 7.97 & 16.8 & 0.38 & CCHDO P02 station 177 \\
\hline AMNH-unkA2 & Laqueus californicus & $\begin{array}{l}34^{\circ} 27^{\prime} \mathrm{N} 120^{\circ} 04^{\prime} \mathrm{W} \\
\text { (Refugio Canyon, } \mathrm{CA} \text { ) }\end{array}$ & 238 & 8.1 & 34.1 & 2213.6 & 2274.6 & 7.74 & 16 & 0.33 & CCHDO P02 station 177 \\
\hline AMNH-322 & Dallinella occidentalis & $\begin{array}{l}33^{\circ} 26^{\prime} \mathrm{N} 118^{\circ} 29^{\prime} \mathrm{W} \\
\text { (Catalina Island, CA) }\end{array}$ & 91 & 10.3 & 33.42 & 2105.6 & 2223.6 & 7.89 & 17.6 & 0.33 & CCHDO P02 station 177 \\
\hline AMNH-535 & Dallinella occidentalis & $\begin{array}{l}33^{\circ} 26^{\prime} \mathrm{N} 118^{\circ} 29^{\prime} \mathrm{W} \\
\text { (Catalina Island, CA) }\end{array}$ & 37 & 15 & 33.54 & 2001.6 & 2211.6 & 8.05 & 17 & 0.33 & CCHDO P02 station 177 \\
\hline AMNH-628 & Magellania venosa & $55^{\circ} 07^{\prime} \mathrm{S} 66^{\circ} 29^{\prime} \mathrm{W}$ (Argentina) & 71 & 1.76 & 33.85 & 2097 & 2277 & 8.18 & 17.1 & 0.33 & GEOSECS \\
\hline AMNH-627 & Magellania venosa & $52^{\circ} 41^{\prime} \mathrm{S} 59^{\circ} 09^{\prime} \mathrm{W}$ (Argentina) & 108 & 7.17 & 33.91 & 2075 & 2285 & 8.15 & 16.3 & 0.351 & CCHDO A17 station 3 \\
\hline
\end{tabular}

Amberlite anion exchange resin. Thermal ionization mass spectrometric analysis was performed on a Thermo Scientific TRITON at the Lamont-Doherty Earth Observatory. Boron isotope ratios were measured in oxide form $\left(\mathrm{BO}_{2}^{-}\right)$, acquiring masses $43\left({ }^{11} \mathrm{~B}^{16} \mathrm{O}_{2}\right)$ and 42 $\left({ }^{10} \mathrm{~B}^{16} \mathrm{O}_{2}\right)$. Filaments were heated over $\sim 20$ minutes at $60 \mathrm{~mA} / \mathrm{min}$ to $980{ }^{\circ} \mathrm{C}$, and then (if necessary) heated very slowly $(10 \mathrm{~mA} / \mathrm{min}$ ) until a signal of at least $100 \mathrm{mV}$ on mass 43 was reached. 240 isotope

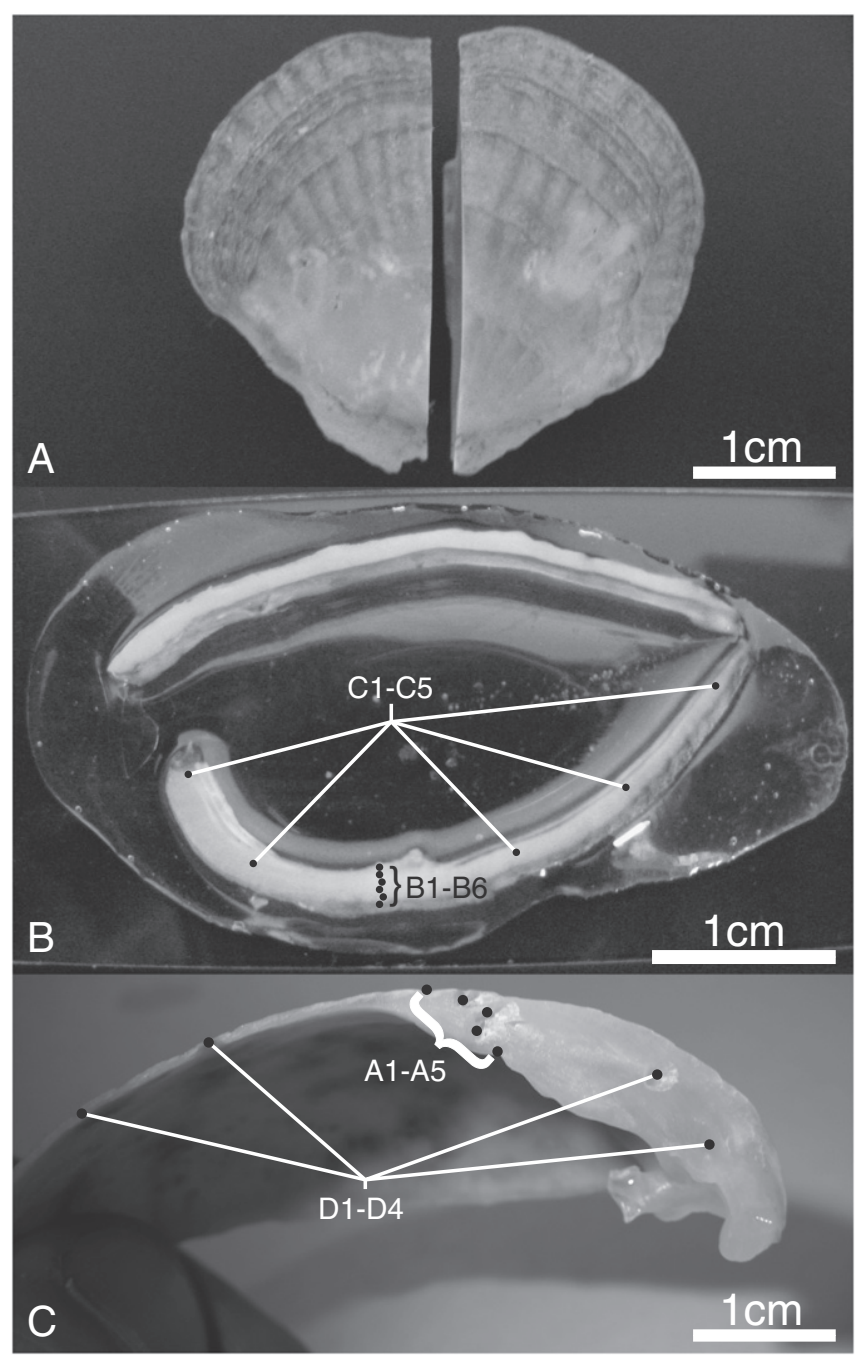

Fig. 2. A) Orientation of cut made for sampling of all specimens. B) Locations of microsampled transects through samples AMNH-unk1 and (C) AMNH-unk4. ratios were acquired over a period of $\sim 25$ minutes. To avoid possible biases resulting from in-run instrumental fractionation, analyses were accepted only if the signal was stable or rising and the measured ratio $(43 / 42)$ varied less than $1 \%$ o throughout the course of the run. One indication of isobaric interference on mass 42 from $\mathrm{CNO}^{-}$ions is the presence of a signal on mass $26\left(\mathrm{CN}^{-}\right)$, but no such signal was detected during any of the runs. Several aliquots of each sample were analyzed and reported data match the criteria of acceptable analyses as outlined above. No temperature effect was observed between measurements over the range of temperatures used. Acceptable analyses gave consistent results between $980{ }^{\circ} \mathrm{C}$ and $1030{ }^{\circ} \mathrm{C}$, although most samples were successfully analyzed at $980{ }^{\circ} \mathrm{C}$. Standards yield sufficiently large signal intensities at $980{ }^{\circ} \mathrm{C}$ and no standard had to be analyzed at temperatures $>980{ }^{\circ} \mathrm{C}$. In the range 920 $980{ }^{\circ} \mathrm{C}$, no temperature dependence of standard values was found, and at temperatures greater than $1000{ }^{\circ} \mathrm{C}$ measuring standards was impossible due to fractionation and unmanageable signal size. Results are reported in conventional delta notation relative to NBS standard 951, calculated as follows:

$\delta^{11} \mathrm{~B}=\left(43 / 42_{\text {sample }} / 43 / 42_{\text {standard }}-1\right) \times 1000$

Boron isotope results are reported in Table 2. Uncertainties are reported either as the internal error, which is calculated as 2 standard errors ( $2 \mathrm{se}=2 \times$ standard deviation $/ \sqrt{ } \mathrm{n}$ ), where $\mathrm{n}$ is the population of repeat analyses of a sample solution, $n>3$, or as the external error, which is 2 se of repeat analyses of an in house $\mathrm{CaCO}_{3}$ standard, using the same number of analyses as collected for a sample. The respective larger error estimate (internal or external) is applied to all figures and statistical evaluations.

For carbon and oxygen isotope analysis, powdered shell calcite was roasted in vacuo for $30 \mathrm{~min}$ at $375{ }^{\circ} \mathrm{C}$ prior to analysis at the University of California Davis on a Fisons Optima isotope ratio mass spectrometer (IRMS) using an Isocarb common acid bath device. Acid reaction temperature was $90{ }^{\circ} \mathrm{C}$. All oxygen and carbon isotope data are presented relative to the Vienna Pee Dee Belemnite (V-PDB) standard using standard per mil (\%) notation where:

$\delta^{18} \mathrm{O}$ and $\delta^{13} \mathrm{C}=\left[\left(\mathrm{R}_{\text {smpl }} / \mathrm{R}_{\text {std }}\right)-1\right] \times 1000$

and $\mathrm{R}={ }^{18} \mathrm{O} /{ }^{16} \mathrm{O}$ and ${ }^{13} \mathrm{C} /{ }^{12} \mathrm{C}$, respectively. Analytical precision $( \pm 1 \sigma)$ of the carbonate $\delta^{18} \mathrm{O}$ and $\delta^{13} \mathrm{C}$ data is $\pm 0.06 \%$ and $0.04 \%$ respectively, based on repeat analyses of an in-house calcite standard.

Oceanographic data for each of the locations listed in Table 1 were compiled from online databases (GEOSECS, GLODAP), published studies, NOAA buoy logs, and personal communications with specialists in regional oceanography (see Table 1 for complete references). For all but one location (Mar del Plata, which is not included in the 
Table 2

Isotope measurements from all specimens. $\delta^{11} \mathrm{~B}$ are averages of 3 replicate analyses of the same sample solution. Bold $\delta^{11} \mathrm{~B}$ (most positive value for each specimen) used for $\mathrm{pH}$ calibration curves, as discussed in the text.

\begin{tabular}{|c|c|c|c|c|c|}
\hline Specimen & $\delta 11 \mathrm{~B}$ & $(+/-)$ & $\delta 180$ & $\delta 13 C$ & Comments \\
\hline \multirow[t]{12}{*}{ AMNH-unkA1 } & 17.53 & 0.43 & 0.22 & 2.27 & B1 (depth transect - inner surface) \\
\hline & 18.83 & 0.38 & 0.28 & 2.48 & B2 \\
\hline & 18.50 & 0.30 & 0.15 & 2.86 & B3 \\
\hline & 18.18 & 0.33 & -0.68 & 1.47 & B4 \\
\hline & 16.51 & 0.39 & -1.10 & -0.46 & B5 \\
\hline & 15.79 & 0.33 & -2.05 & -2.07 & B6 (depth transect - outer surface) \\
\hline & 18.63 & 0.46 & 0.03 & 1.44 & C1 (length transect - anterior, hinge) \\
\hline & 18.21 & 0.33 & 0.01 & 2.23 & $\mathrm{C} 2$ \\
\hline & 18.59 & 0.38 & 0.21 & 2.40 & $\mathrm{C} 3$ \\
\hline & 18.56 & 0.38 & 0.23 & 2.60 & $\mathrm{C} 4$ \\
\hline & 18.11 & 0.38 & -0.23 & 2.20 & C5 (length transect - posterior) \\
\hline & 14.61 & 0.33 & & & Repeat of B3, ashed in oven \\
\hline \multirow[t]{12}{*}{ AMNH-unkA4 } & 16.80 & 0.53 & 2.77 & 2.41 & A1 (depth transect - innter surface) \\
\hline & 17.61 & 0.33 & 2.53 & 2.85 & $\mathrm{~A} 2$ \\
\hline & 17.04 & 0.33 & 2.52 & 2.56 & A3 \\
\hline & 14.76 & 0.38 & 2.56 & 2.71 & A4 \\
\hline & 14.14 & 0.57 & 0.69 & -0.05 & A5 (depth transect - outer surface) \\
\hline & & & 2.40 & 2.08 & D1 (length transect - anterior, hinge) \\
\hline & & & 2.07 & 1.56 & $\mathrm{D} 2$ \\
\hline & & & 2.37 & 2.50 & D3 \\
\hline & & & 2.39 & 2.63 & D4 \\
\hline & & & 2.43 & 2.49 & D5 (length transect - posterior) \\
\hline & 15.10 & 0.49 & & & Repeat of A5,ashed in oven \\
\hline & 16.66 & 0.33 & & & Repeat of $\mathrm{A} 2$, ashed in oven \\
\hline \multirow[t]{2}{*}{ AMNH-499 } & 16.55 & 0.27 & & & \\
\hline & 16.50 & 0.38 & & & \\
\hline \multirow[t]{4}{*}{ AMNH-535 } & 16.91 & 0.38 & & & \\
\hline & 16.16 & 0.33 & & & \\
\hline & 16.97 & 0.33 & & & \\
\hline & 15.95 & 0.38 & & & \\
\hline AMNH-322 & 17.56 & 0.33 & & & \\
\hline AMNH-unkA2 & 16.00 & 0.33 & & & \\
\hline \multirow[t]{2}{*}{ AMNH-unkA3 } & 16.82 & 0.38 & & & \\
\hline & 15.91 & 0.33 & & & \\
\hline AMNH-628 & 17.06 & 0.33 & & & \\
\hline AMNH-627 & 16.30 & 0.351 & & & \\
\hline
\end{tabular}

$\mathrm{pH}-\delta^{11} \mathrm{~B}$ comparison due to imprecise knowledge of regional carbonate chemistry), data were found to constrain temperature, pressure (inferred from depth of collection), salinity, total alkalinity, and dissolved inorganic carbon. From these parameters we are able to calculate the entire carbonate system using CO2SYS (Pierrot et al., 2006), including in situ $\mathrm{pH}$ on the seawater scale.

Two specimens were microsampled for $\delta^{18} \mathrm{O}$, including one specimen from the eastern north Pacific/Southern California Bight in the San Pedro Basin, and another from the southwestern Atlantic off Mar del Plata, Argentina. Equilibrium $\delta^{18} \mathrm{O}$ values were computed using local $\delta^{18} \mathrm{O}_{\text {seawater }}$ and ambient temperatures (Table 1). For the Southern California Bight, $\delta{ }^{18} \mathrm{O}_{\text {seawater }}$ is calculated from salinity using

$\delta^{18} \mathrm{O}_{\text {seawater }}=0.39^{*} \mathrm{~S}-13.23$

(Bemis et al., 2002). For the South Atlantic, $\delta^{18} \mathrm{O}_{\text {seawater }}$ is calculated using

$\delta{ }^{18} \mathrm{O}_{\text {seawater }}=0.51^{*} \mathrm{~S}-17.4$

(LeGrande and Schmidt, 2006). Equilibrium calcite $\delta^{18} \mathrm{O}$ is computed by inverting the temperature- $\delta{ }^{18} \mathrm{O}$ relationship of Epstein et al. (1953):

$$
\begin{aligned}
\mathrm{T}\left({ }^{\circ} \mathrm{C}\right)= & 16.5-4.3\left(\delta^{18} \mathrm{O}_{\text {carbonate }}-\delta^{18} \mathrm{O}_{\text {seawater }}\right) \\
& +0.14\left(\delta^{18} \mathrm{O}_{\text {carbonate }}-\delta^{18} \mathrm{O}_{\text {seawater }}\right)^{2}
\end{aligned}
$$

Here, $\delta^{18} \mathrm{O}_{\text {seawater }}$ is converted from the V-SMOW to V-PDB scale by subtracting $0.20 \%$ (Bemis et al., 1998). Note that this V-SMOW to V-PDB correction differs from the more recent value of $0.27 \%$ of Hut (1987) because $0.2 \%$ o was the accepted correction at the time when Epstein et al. (1953) established their empirical calibration.

\section{Results and discussion}

\subsection{Intrashell $\delta^{18} \mathrm{O}$ and $\delta^{13} \mathrm{C}$ variability}

Carbon and oxygen isotope measurements of transects through shells of $M$. venosa and $T$. transversa show that the inner part of the fibrous secondary layer is precipitated in oxygen isotopic equilibrium with ambient seawater, in agreement with previous studies (Fig. 3A, B, Auclair et al., 2003; Brand et al., 2003; Parkinson et al., 2005; Brand et al., 2011). In contrast, the $\delta^{18} \mathrm{O}$ values in the exterior primary layer, and in the case of $T$. transversa also in the exterior part of the secondary layer, are depleted in $\delta^{18} \mathrm{O}$ by $\sim 2 \%$ relative to the secondary layer equilibrium values (Fig. 3A, B). Similar isotope trends are seen in $\delta^{13} \mathrm{C}$ of the two species, with more negative values in the outer primary layer and more positive values in the inner, secondary layer.

Cross-plots of $\delta^{18} \mathrm{O}$ and $\delta^{13} \mathrm{C}$ (Fig. 4A) show that trends in the two isotope systems in the primary and outer secondary layers co-vary (Fig. 3A), suggesting that kinetic effects could be influencing the geochemistry of the outer layer. This effect, which was also recognized by previous studies of $\delta^{18} \mathrm{O}$ and $\delta^{13} \mathrm{C}$ in brachiopod shells (Auclair et al., 2003; Brand et al., 2003), can result from differences in the reaction rate of the hydration of $\mathrm{CO}_{2}$ (the slowest reaction in the equilibration of the carbonate system), which depend on whether ${ }^{13} \mathrm{C}$ or ${ }^{12} \mathrm{C}$ is used. Such an effect can only manifest itself in the ultimately produced $\mathrm{CaCO}_{3}$ if the reaction does not go to completion (i.e. if the dissolved inorganic pool is not entirely consumed) (Auclair et al., 2003).

\subsection{Intrashell $\delta^{11} B$ variability}

Boron isotope measurements range from 14 to $19 \%$ ond show a total range of $\sim 3 \%$ in each species. Similar to $\mathrm{C}$ and $\mathrm{O}$ isotopes, $\delta^{11} \mathrm{~B}$ is more negative in the primary relative to the outer secondary layers, but unlike $\mathrm{C}$ and $\mathrm{O}$ isotope trends, $\delta^{11} \mathrm{~B}$ values are also more negative

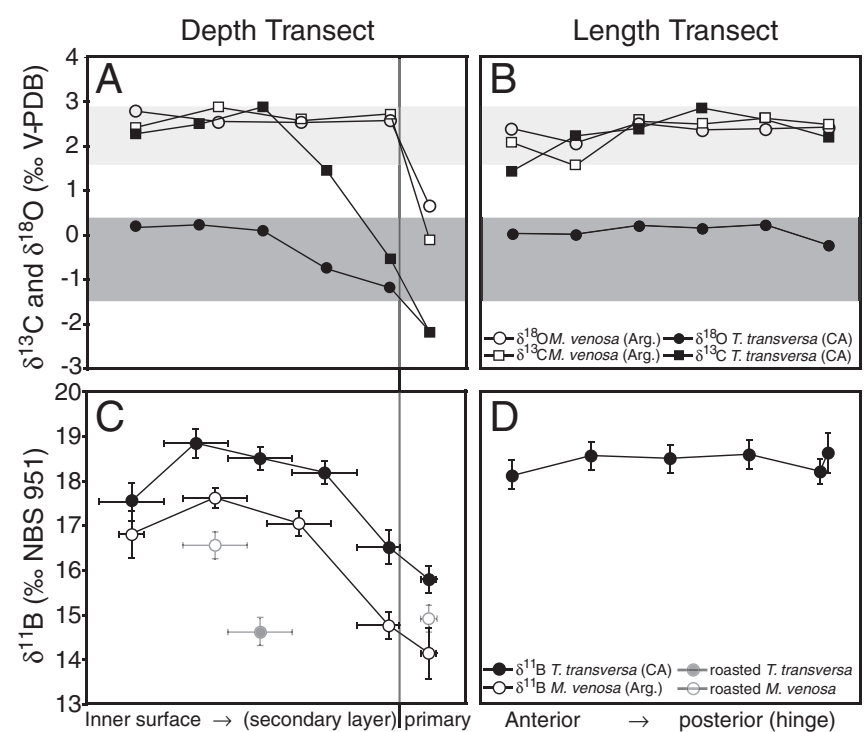

Fig. 3. Depth and length transects of, $\delta^{13} \mathrm{C}, \delta^{18} \mathrm{O}$ and $\delta^{11} \mathrm{~B}$ through $T$. transversa from San Pedro, CA (sample AMNH-unk2; closed symbols) and M. venosa from Mar Del Plata, Argentina (sample AMNH-unk4; open symbols). In Figures A and B, circles and squares are $\delta^{18} \mathrm{O}$ and $\delta{ }^{13} \mathrm{C}$ data, respectively. Dark and light grey bars are calculated $\delta^{18} \mathrm{O}$ equilibrium values from oceanographic data for $T$. transversa and $M$. venosa, respectively. Grey symbols in C and D identify samples that were ashed prior to $\delta^{11} \mathrm{~B}$ analysis. 


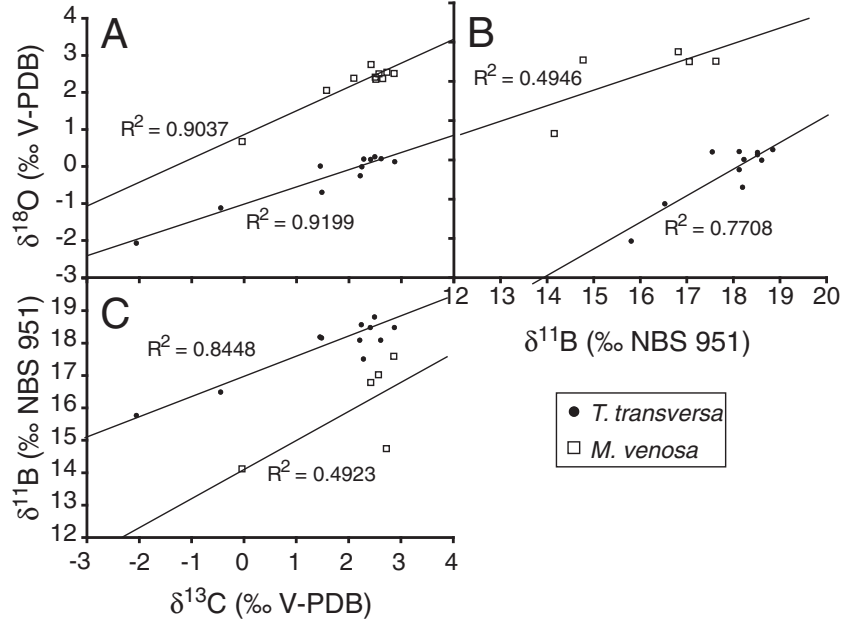

Fig. 4. Correlation between $\delta^{11} \mathrm{~B}, \delta^{18} \mathrm{O}$, and $\delta^{13} \mathrm{C}$ from microsampled depth and length transects in AMNH-unk1 (T. transversa) and AMNH-unk4 (M. venosa).

in the innermost part of the secondary layer (Fig. 3C). Reproducible $\delta^{11} \mathrm{~B}$ values are found in the center of the secondary layer, and those data are in the same range as $\delta^{11} \mathrm{~B}$ values published for a wide range of modern marine carbonates (Hemming and Hanson, 1992). We have therefore selected the isotopically homogenous secondary layer of the shell for the $\mathrm{pH}$-calibration in this study. Within this middle part of the secondary layer, we observe little variation from the anterior to posterior section of the shell. Hence, samples were obtained from the thickest midpoint along the shell, so that sufficient material could be obtained for analysis. The high degree of similarity in $\delta{ }^{11} \mathrm{~B}$ trends in the two species suggests that the observed trends may be a characteristic of articulate brachiopods in general.

The three samples that were re-drilled and roasted as a second test for removing potentially interfering organic matter showed highly variable (in both direction and magnitude) effects of roasting on $\delta^{11} \mathrm{~B}$. In fact, two of the three gave more negative values after roasting, the opposite of what would be expected if roasting actually removed interfering $\mathrm{CNO}^{-}$. This suggests that organic interference is not responsible for the observed trend. Given the negative deviation from the untreated samples (up to - 5\%), it appears that baking introduces a bias to the $\delta^{11} \mathrm{~B}$ measurement, possibly through ${ }^{11} \mathrm{~B}$ loss at $375{ }^{\circ} \mathrm{C}$ or boron or organic contamination. Based on the results of these baking experiments and the good agreement with previously published $\delta^{11} \mathrm{~B}$ data from modern $T$. transversa measured by ICP-MS (Lécuyer et al., 2002), we conclude that organic interference is not an issue in NTIMS measurement of $\delta^{11} \mathrm{~B}$ in brachiopod calcite.

Boron isotopes co-vary with both $\delta^{18} \mathrm{O}$ and $\delta^{13} \mathrm{C}$ (Fig. 4B, C), although not as systematically as $\delta^{18} \mathrm{O}$ co-varies with $\delta^{13} \mathrm{C}$. Boron samples were drilled from the same sample pits but were not the same aliquots that were used for carbon and oxygen isotope analysis. The weaker correlation between $\delta^{11} \mathrm{~B}$ and $\delta^{13} \mathrm{C} / \delta^{18} \mathrm{O}$ could possibly be affected by local isotopic heterogeneity but because the isotope deviations are systematic within a shell and between shells of different specimens, local isotopic heterogeneity seems an unlikely explanation for the observed patterns. The region of the shell in which the $\delta^{11} \mathrm{~B}$ covariance breaks down is the innermost secondary layer, where $\delta^{18} \mathrm{O}$ remains within the range of equilibrium values and $\delta^{13} \mathrm{C}$ remains in the range of mid-shell values, but $\delta^{11} \mathrm{~B}$ becomes depleted relative to the consistently more positive values found near the middle of the shell.

The similarity of the $\mathrm{B}, \mathrm{C}$ and $\mathrm{O}$ isotope profiles could suggest that all three isotope systems are controlled by the same process, which Auclair et al. (2003) have suggested may be kinetic fractionation in the case of $\mathrm{C}$ and $\mathrm{O}$ isotopes. However, $\delta^{11} \mathrm{~B}$ values decrease in the inner region of the shell and thus deviate from the $\mathrm{O}$ and $\mathrm{C}$ isotope pattern. Because it is unlikely that kinetic effects would affect boron isotopes due to the relatively fast isotopic equilibration of boric acid with borate $(\sim 125 \mu$ s, Zeebe et al., 2001), we favor a physiological explanation that could involve lower $\mathrm{pH}$ in the metabolic fluid of the organism, or a $\mathrm{pH}$ gradient across the calcifying surface of the shell that has an ontogenetic component. Brachiopods build their shells by incrementally extending the single-crystal fibers that make up the secondary layer (Williams et al., 1997; Greisshaber et al., 2007) from the hinge towards the anterior of the shell, along the inner shell surface (Ackerly, 1989). Thus, each increment of growth involves the secretion of secondary material along the inner surface of the shell and primary calcite along the anterior shell edge (Fig. 5). In our transects the innermost calcite of the secondary layer represents the newest shell material, secreted just before the animal died, while the outermost calcite represents older material secreted at a younger ontogenetic stage. Therefore the cause of the observed trends in $\mathrm{B}, \mathrm{C}$, and $\mathrm{O}$ isotopes remain unclear and could be related to a variety of factors: environmental changes during the lifetime of the brachiopod, physiological processes such as growth rate, respiration, and calcification that may change during ontogeny and affect different parts of the calcifying surface differently, and finally different dynamics in the secretion of primary vs. secondary calcite.

\subsection{Recommended sampling strategy for future studies}

Intrashell variability introduces complications to the use of brachiopod calcite $\delta^{11} \mathrm{~B}$ as a recorder of paleo-pH. Careful sampling is required to consistently sample the same point on the $\delta^{11} \mathrm{~B}$ trend throughout the shell. We recommend sampling at the midpoint of the ventral valve (with respect to shell thickness) at the thickest point along its length, which was the method used for the rest of our modern specimens. The reasons for this recommendation are twofold: firstly, this point has the most stable and most positive $\delta^{11} \mathrm{~B}$ values and equilibrium $\delta^{18} \mathrm{O}$, and secondly, being in the middle of the shell, it is less vulnerable to alteration and potential diagenetic alteration than any of the shell surfaces in fossil specimens. In some particularly thin modern shells we found it necessary to resample numerous times in an effort to obtain the middle-most calcite. If such re-sampling did not provide consistent results, only the most positive value obtained appears reliable for $\mathrm{pH}$ calculations. One benefit of the observed intrashell variability is that it provides a simple test for B-alteration in fossil specimens which may be of particular concern in fossil Terebratulids given the vulnerability of their punctate shells (Pérez-Huerta et al., 2009) to diagenetic alteration. If the depth trend in $\delta^{11} \mathrm{~B}$ is observed, one can be reasonably certain that the calcite is original and unaltered, whereas alteration would tend to homogenize the signal.

\section{4. $\delta^{11} B-p H$ relationship}

Because the specimens were collected from known oceanographic locations, we can evaluate the $\delta^{11} \mathrm{~B}$ against $\mathrm{pH}$ estimated from oceanographic data (Fig. 6). Due to the different methods used to measure or calculate $\mathrm{pH}$ from oceanographic data for each sample and seasonal

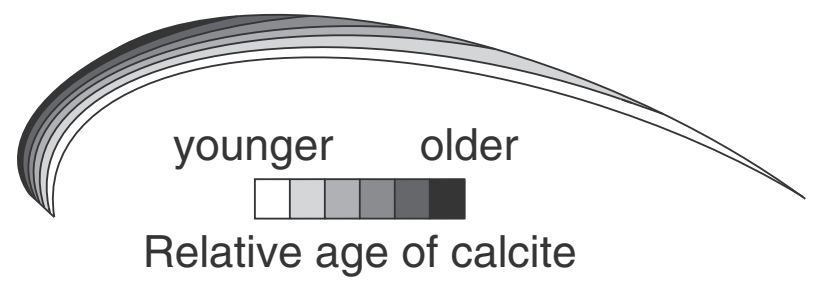

Fig. 5. Schematic representation of incremental calcification in brachiopod shells (after Ackerly, 1989). 


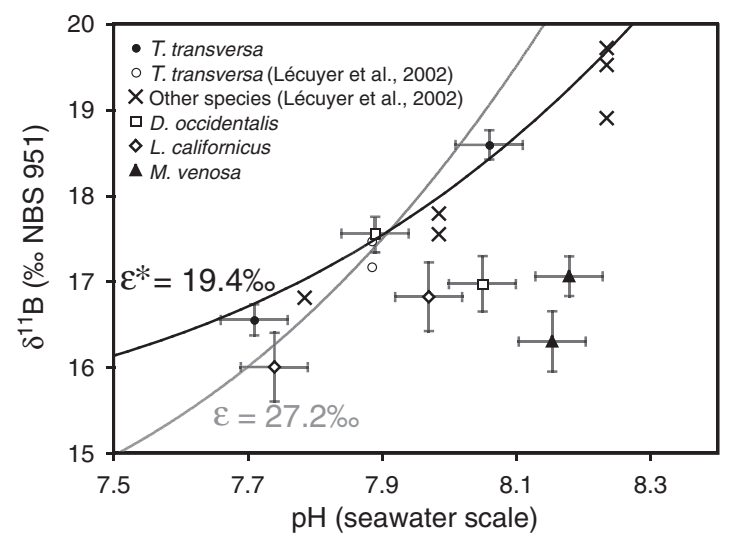

Fig. 6. $\delta^{11} \mathrm{~B}$ vs. $\mathrm{pH}$ relationship for all species. Solid and grey lines are predicted borate $\delta^{11} \mathrm{~B}$ curves using the empirical carbonate fractionation $\left(\varepsilon^{*}\right)$ and the measured aqueous fractionation $\varepsilon$ after Klochko et al. (2006), respectively. Both curves adjusted with constant offset to best fit data for T. transversa.

variations in $\mathrm{pH}$ for some locations, an arbitrary but sufficiently large uncertainty of $\pm 0.05 \mathrm{pH}$ units is assumed for each sample. In many cases we performed replicate analyses of separately drilled and cleaned samples from the same specimen (Table 2). As discussed above, when values differ only the most positive value is considered for calibration purposes. Also shown are the ICP-MS analyses of brachiopod calcite by Lécuyer et al. (2002) after re-calculating their measured $\mathrm{pH}$ values from the NBS scale to the seawater scale for direct comparison to this study. Because samples were collected from a variety of temperature $(\mathrm{T})$, salinity (S), and pressure (p) conditions, all of which affect the dissociation constants of carbonic acid (Mehrbach et al., 1973) and boric acid (Dickson, 1990) (i.e. $\mathrm{pK}_{1}, \mathrm{pK}_{2}$, and $\mathrm{pK}_{\mathrm{B}}$ ), no single slope can be used as a $\delta^{11} \mathrm{~B}_{\text {borate }}$ calibration curve.

The calibration is complicated by a conflict between observations of aqueous boron fractionation in seawater and an apparently smaller fractionation between seawater and carbonates. At the time of the first efforts to document and quantify the $\delta^{11} \mathrm{~B}$ vs. pH relationship in marine carbonates, the theoretical fractionation of Kakihana et al. (1977), $\varepsilon=19.4 \%$, was the only estimate available and fit (within error) the calibration work done on planktic foraminifera and corals. Subsequently, Klochko et al. (2006) empirically determined the aqueous fractionation between boric acid and borate in seawater using spectrophotometric $\mathrm{pH}$ measurements and obtained a result of $\varepsilon=$ $27.2 \%$, which translates to a larger $\delta^{11} \mathrm{~B}$ increase per incremental $\mathrm{pH}$ increase than predicted by early theory. So we are left with a conundrum: without application of any corrections, all empirical calibration curves of carbonates grown over a wide $\mathrm{pH}$ range (Sanyal et al., 1996, 2000, 2001; Hönisch et al., 2004; Reynaud et al., 2004; Krief et al., 2010; Trotter et al., 2011) display a lower pH-sensitivity than that predicted by the actual aqueous fractionation measured by Klochko et al (2006). Perhaps the boron incorporation mechanism of Hemming and Hanson (1992) is incomplete, or perhaps the fractionation between dissolved boron in seawater and marine carbonates is complicated by variable activities of dissolved ions in seawater, but either way it is unclear which fractionation factor is appropriate for producing brachiopod $\delta^{11} \mathrm{~B}$ vs. pH calibration curves. For visual comparison two possible calibration curves are shown in Fig. 5, one using the empirical carbonate fractionation $\varepsilon^{*} \sim 20 \%$ 。 (Hönisch et al., 2007), and one using the actual aqueous fractionation $\varepsilon=27.2 \%$ o (Klochko et al., 2006). For all calibration curves discussed below the $\delta^{11} \mathrm{~B}$ vs. $\mathrm{pH}$ relationship is described by the following equation:

$$
\begin{aligned}
\mathrm{pH}= & \mathrm{p} K_{\mathrm{B}}-\log \left(-\left(\delta^{11} \mathrm{~B}_{\text {seawater }}-\delta^{11} \mathrm{~B}_{\text {sample }}-a\right)\right. \\
& \left./\left(\delta^{11} \mathrm{~B}_{\text {seawater }}-\alpha \cdot\left(\delta^{11} \mathrm{~B}_{\text {sample }}+a\right)-\varepsilon\right)\right),
\end{aligned}
$$

where $\mathrm{p} K_{\mathrm{B}}$ is calculated for each sample as a function of $\mathrm{T}, \mathrm{S}$, and $\mathrm{p}$ using the equations of Dickson (1990) for temperature and salinity effects, and Millero (1995) for pressure effects. $\delta^{11} B_{\text {seawater }}$ is $39.6 \%$ (Foster et al., 2010), $a$ is the species-specific offset optimized for best fit, $\alpha$ (respectively $\alpha^{*}$ ) is the fractionation factor and $\varepsilon$ (respectively $\varepsilon^{*}$ ) the fractionation for the aqueous boron fractionation (respectively fractionation between seawater and marine carbonates). Similar to previous calibrations, the brachiopod boron isotope data do not fall on either the theoretical or the empirical aqueous $\delta^{11} \mathrm{~B}_{\text {borate }}$ curve, necessitating a constant offset for each species. We shifted the curves along the $y$-axis by choosing an offset $a$ that places the $\delta^{11} \mathrm{~B}$ data for T. transversa onto each borate curve. The $\mathrm{T}, \mathrm{S}$, and $\mathrm{p}$ (which affect $\mathrm{p} K_{\mathrm{B}}$ ) used in the calibration curves shown in Fig. 5 are average values for the $T$. transversa specimens. We chose $T$. transversa for this exercise because this species spans the greatest $\mathrm{pH}$ range and it shows the clearest $\delta^{11} \mathrm{~B}$ vs. $\mathrm{pH}$ relationship. This procedure is analogous to previous calibration strategies to correct for species-specific vital effects in foraminifera and corals (Sanyal et al., 2001; Hönisch and Hemming, 2004; Hönisch et al., 2004).

The relationship for $T$. transversa is consistent across a wide range of $\mathrm{pH}$, including new data measured by NTIMS (this study) as well as previously published data measured on bulk shells by ICP-MS (Lécuyer et al., 2002), and follows closely the slope observed in all other marine carbonates. However, using the aqueous fractionation of Klochko et al. (2006) requires smaller offsets. Given the uncertainty in $\mathrm{pH}$ calculations, the small number of specimens per species and the relatively small $\mathrm{pH}$ range (7.7-8.2), the sensitivity of the $\delta^{11} \mathrm{~B}$ vs. pH relationship cannot be determined with certainty. Comparison of the T. transversa data to other brachiopod species reveals a high degree of variability in absolute $\delta^{11} \mathrm{~B}$ (Fig. 6), requiring that species-specific offsets be further taken into account. Notably, while the relationships for $T$. transversa and $L$. californicus follow the slope of other carbonates calibrated over a wide $\mathrm{pH}$ range in the laboratory, the data for $M$. venosa, although covering only a small range of $\mathrm{pH}$ with two points, seem to follow a $\delta{ }^{11} \mathrm{~B}$ vs. $\mathrm{pH}$ relationship that may be more compatible with the sensitivity of the borate curve of Klochko et al. (2006). The trend of one particularly thin-shelled (and thus difficult to sample accurately) species ( $D$. occidentalis) is even in the opposite sense, and likely illustrates the impact of intrashell variability and the need for careful, consistent sampling practices.

In order to quantitatively evaluate the fit of these two alternative sensitivities to the data from each species, we compare measured $\delta^{11} \mathrm{~B}$ to that predicted using both the empirical carbonate fractionation $\varepsilon^{*}$ and the measured fractionation $\varepsilon$ of Klochko et al. (2006) (Fig. 7). For simplicity, no temperature correction (Honisch et al., 2008; Rustad et al., 2010) is applied to either of the fractionation factors in Fig. 7, as we found that it does not improve the fit between predicted and measured $\delta^{11} \mathrm{~B}$, although the effects of temperature correction would be smaller than the uncertainty of $\delta^{11} \mathrm{~B}$ measurements, so cannot be ruled out by our data. As it is evident from the $\delta^{11} \mathrm{~B}$ variation between species (Fig. 6) that specific offsets need to be taken into account, we have included in Fig. 7 a constant offset (a) for each species that optimizes the fit between predicted and measured $\delta^{11} \mathrm{~B}$. Values for $a$ used for calibration curves using the $\varepsilon^{*}$ are as follows: $L$. californicus $a=-4.8 \%$, $T$. transversa $a=-4.1 \%$. Using $\varepsilon$ (Klochko et al., 2006), L. californicus $a=1.8 \%$, T. transversa $a=2.4 \%$. Due to coverage by only two points and large disagreement with the slope of either fractionation curve, offsets cannot be meaningfully calculated for $M$. venosa or D. occidentalis. Similar to previous calibrations of boron isotopes in marine carbonates, boron fractionation into brachiopod shells appears less sensitive than predicted by the aqueous fractionation of Klochko et al. (2006). Data from $M$. venosa form an exception from this general observation as they produce a negative correlation between $\delta{ }^{11} \mathrm{~B}_{\text {predicted }}$ and $\delta{ }^{11} \mathrm{~B}_{\text {observed }}$ using either sensitivity. 

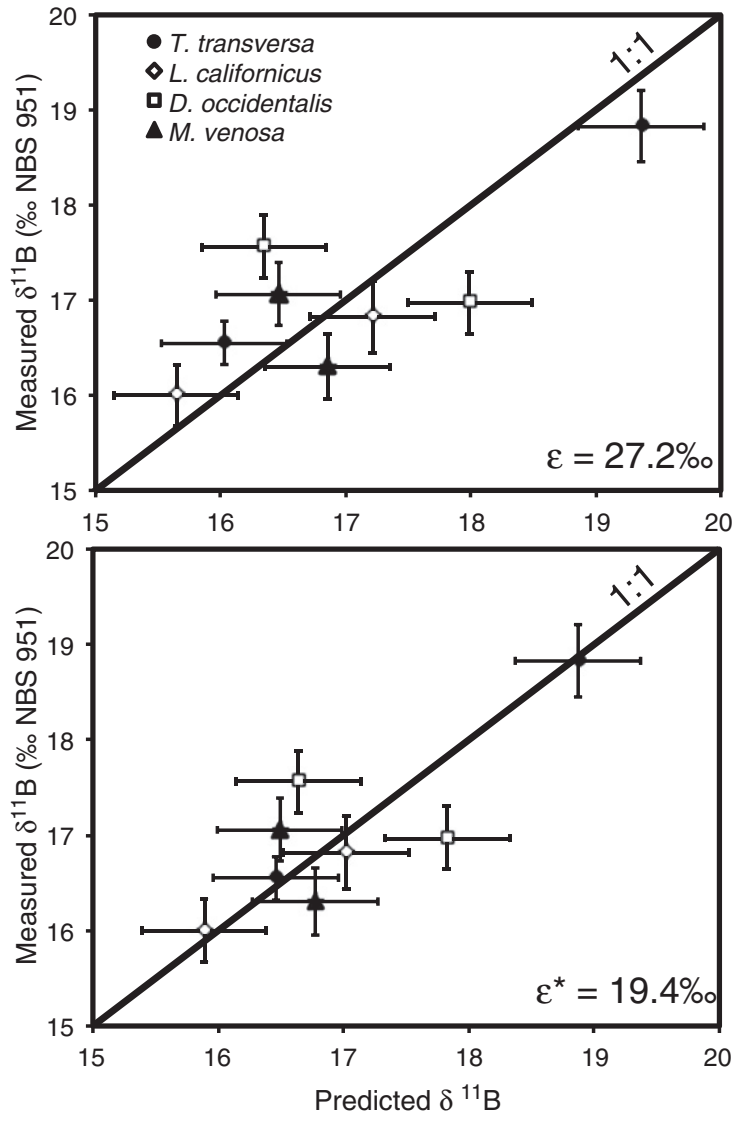

Fig. 7. Predicted vs. measured $\delta^{11} \mathrm{~B}$ using optimized species-specific calibration curves with the fractionation factor of Klochko et al. (2006) (top panel) and the smaller fractionation factor of previous calibrations $\left(\varepsilon^{*}\right)$ (bottom panel). $\delta^{11} \mathrm{~B}$ is predicted for each specimen from oceanographic data using the $\delta^{11} \mathrm{~B}$ vs. $\mathrm{pH}$ relationship and using a species-specific offset $(a)$ optimized for the best measured vs. predicted fit.

\section{Conclusions}

Depth and length transects of articulate brachiopod shells confirm previous studies investigating the intrashell variability of carbon and oxygen isotopic composition of brachiopod calcite. The trend of increasing isotope values from the primary to the secondary layer is interpreted in this and previous studies as a kinetic effect, where the interior parts of the secondary layer are precipitated closer to equilibrium with seawater. The results generally support the use of fossil brachiopods as recorders of those isotopic systems, as long as care is taken to only sample the inner secondary layer. The trends in boron isotopic composition along the same transects are similar to trends observed in carbon and oxygen isotopes. Where carbon and oxygen isotopes may be explained by kinetic fractionation during shell growth, boron isotopes equilibrate extremely rapidly between aqueous boron species, and kinetic fractionation therefore seems unlikely. In addition, the secondary innermost layer is depleted in $\delta^{11} \mathrm{~B}$ but not in $\delta{ }^{13} \mathrm{C}$ and $\delta{ }^{18} \mathrm{O}$. Therefore, a separate mechanism must control the boron isotopic composition of the innermost secondary layer. A pH gradient across the calcifying surface may explain the observed trends, where respiration of the animal and calcification may decrease $\mathrm{pH}$ in the calcifying fluid adjacent to the shell.

The intrashell variability is significant yet systematic, so consistent, careful sampling of the midpoint of the shell at its thickest point is recommended to minimize possible additional uncertainties on $\delta^{11} \mathrm{~B}$-based $\mathrm{pH}$ reconstructions. The pattern of variability in carbon, oxygen and boron isotopic composition also provides a useful test of diagenetic alteration or replacement in brachiopod calcite.
The $\delta^{11} \mathrm{~B}$ vs. $\mathrm{pH}$ relationships for species $T$. transversa and L. californicus are consistent with published empirical calibrations of other marine carbonates and display a lower sensitivity than predicted from aqueous boron fractionation. Similar to (Honisch et al., 2007) we adjust the empirical $\delta^{11} \mathrm{~B} / \mathrm{pH}$ relationship by using a smaller empirical fractionation factor $\left(\alpha^{*}\right)$ instead of the actual aqueous fractionation factor ( $\alpha$, Klochko et al., 2006). This adjustment is practical and simple but should not be interpreted as an indication that we understand the reason for the lower $\delta^{11} \mathrm{~B} / \mathrm{pH}$ sensitivity in marine carbonates. To obtain the best match between $\delta^{11} \mathrm{~B}$ in brachiopods and predicted seawater-pH an additional empirical offset of $\mathrm{a}=$ $-4.2 \%$ and $-4.8 \%$ is used for T. transversa and L. californicus, respectively. In contrast, using the actual fractionation factor of Klochko et al. (2006) requires smaller empirical offsets $(a=1.8 \%$ ond $2.4 \%$, respectively) but does not create as good a match with observed seawater-pH. Because the lower sensitivity emerges as a universal pattern in marine carbonates, we recommend its use for paleo-pH reconstructions. However, species-specific vital effects and uncertainties in the growth habitat of fossil brachiopods probably pose a greater problem for $\mathrm{pH}$ estimates than the $\delta^{11} \mathrm{~B}$ sensitivity to $\mathrm{pH}$. Paleo-pH reconstructions therefore must focus on single species or ensure that species-differences are constant and cross-calibration of coeval species would be required for reconstructions of the Mesozoic and Paleozoic. In particular Terebratulids, to which $T$. transversa belongs, extend from the Carboniferous to the present and thus allow for reconstructions using closely related species. However, absolute calculations of $\mathrm{pH}$ are further complicated by uncertainty in the $\delta^{11} \mathrm{~B}$ of ambient seawater, which model simulations (Lemarchand et al., 2000, 2002; Joachimski et al., 2005; Simon et al., 2006) suggest has varied significantly on timescales longer than the $10-20$ My residence time of boron in seawater.

Further investigations into the boron isotopic composition of brachiopod calcite may refine or expand its use in reconstructing $\mathrm{pH}$ of ancient seawater. Culturing brachiopods in laboratory conditions, where parameters of the carbonate system are carefully controlled, a technique that has proven invaluable in calibrating foraminifera, corals, and synthetic calcite, would certainly refine the proxy for different species. A comparison of $\delta^{11} \mathrm{~B}$ in Cenozoic fossil specimens to published Cenozoic foraminifera could be used to calibrate extinct brachiopod species that would be of greater use in pre-Cenozoic paleo-pH reconstructions. Investigating the concentration of trace metals whose incorporations have been shown to be sensitive to carbonate system parameters (U/Ca, B/Ca, Mg/Ca, etc.) (Russell et al., 2004) could provide additional insights into the causes of intrashell $\delta^{11} \mathrm{~B}$ variability.

\section{References}

Ackerly, S.C., 1989. Kinematics of accretionary shell growth, with examples from brachiopods and molluscs. Paleobiology 15 (2), 147-164.

Angiolini, L., et al., 2012. Heterogeneity, cyclicity and diagenesis in a Mississippian brachiopod shell of palaeoequatorial Britain. Terra Nova 24 (1), 16-26.

Auclair, A.-C., Joachimski, M.M., LĖcuyer, C., 2003. Deciphering kinetic, metabolic and environmental controls on stable isotope fractionations between seawater and the shell of Terebratalia transversa (Brachiopoda). Chemical Geology 202 (1-2), 59-78.

Bemis, B.E., Spero, H.J., Bijma, J., Lea, D.W., 1998. Reevaluation of the oxygen isotopic composition of planktonic foraminifera: experimental results and revised paleotemperature equations. Paleoceanography 13 (2), 150-160.

Bemis, B.E., Spero, H.J., Thunell, R.C., 2002. Using species specific paleotemperature equations with foraminifera: a case study in the Southern California Bight. Marine Micropaleontology 46, 26.

Berelson, W., 1985. Studies of Water Column Mixing and Benthic Exchange of Nutrients. Carbon and Radon in the Southern California Borderland. University of Southern California (219 pp.).

Berner, R.A., 1975. The role of magnesium in the crystal growth of calcite and aragonite from sea water. Geochimica et Cosmochimica Acta 39 (4), 489-494.

Berner, R.A., Kothavala, Z., 2001. GEOCARB III: a revised model of atmospheric CO2 over phanerozoic time. American Journal of Science 301 (2), 182-204.

Brand, U., Logan, A., Hiller, N., Richardson, J., 2003. Geochemistry of modern brachiopods: applications and implications for oceanography and paleoceanography. Chemical Geology 198 (3-4), 305-334. 
Brand, U., et al., 2011. What is the ideal proxy of Palaeozoic seawater chemistry? Memoirs of the Association of Australasian Palaeontologists 41, 9

Buening, N., Spero, H.J., 1996. Oxygen- and carbon-isotope analyses of the articulate brachiopod Laqueus californianus: a recorder of environmental changes in the subeuphotic zone. Marine Biology 127, 105-114.

Carpenter, S.J., Lohmann, K.C., 1995. Delta-O-18 and delta-C-13 values of modern brachiopod shells. Geochimica et Cosmochimica Acta 59 (18), 37.

Compston, W., 1960. The carbon isotopic compositions of certain marine invertebrates and coals from the Australian Permian. Geochimica et Cosmochimica Acta 18, 1-22.

Curry, G.B., Fallick, A.E., 2002. Use of stable oxygen isotope determinations from brachiopod shells in palaeoenvironmental reconstruction. Palaeogeography, Palaeoclimatology, Palaeoecology 182, 122-143.

Dall, W.H., 1871. Report on the "Brachiopoda" Obtained by the United States Coast Survey Expedition, in Charge of LF de Pourtalès, with a Revision of the "Cramiidae" and "Discinidae", by WH Dall. University Press.

Dickson, A.G., 1990. Thermodynamics of the dissociation of boric acid in synthetic seawater from 273.15 to 318.15 K. Deep Sea Research 37, 755-766.

Epstein, S., Buchsbaum, R., Lowenstam, H.A., Urey, H.C., 1953. Revised carbonate-water temperature scale. Bulletin of the Geological Society of America 64, 1315-1326.

Foster, G.L., 2008. Seawater pH, pCO2 and [CO2-3] variations in the Caribbean Sea over the last 130†kyr: a boron isotope and B/Ca study of planktic foraminifera. Earth and Planetary Science Letters 271 (1-4), 254-266.

Foster, G., von Strandmann, P.A.E.P., Rae, J., 2010. Boron and magnesium isotopic composition of seawater. Geochemistry, Geophysics, Geosystems 11 (8), Q08015.

Goetz, A.J., et al., 2009. Calcite morphology, texture and hardness in the distinct layers of rhynchonelliform brachiopod shells. European Journal of Mineralogy 21 (2), 303-315.

Greisshaber, E., et al., 2007. Crystallographic texture and microstructure of terebratulide brachiopod shell calcite: an optimized materials design with hierarchical architexture. American Mineralogist 92, 722-734.

Grossman, E.L., Mii, H.S., Zhang, C., Yancey, T.E., 1996. Chemical variation in Pennsylvanian brachiopod shells; diagenetic, taxonomic, microstructural, and seasonal effects. Journa of Sedimentary Research 66 (5), 1011-1022.

Grossman, E.L., et al., 2008. Glaciation, aridification, and carbon sequestration in the Permo-Carboniferous: the isotopic record from low latitudes. Palaeogeography, Palaeoclimatology, Palaeoecology 268, 222-233.

Hemming, N.G., Hanson, G.N., 1992. Boron isotopic composition and concentration in modern marine carbonates. Geochimica et Cosmochimica Acta 56, 537-543.

Hönisch, B., Hemming, N.G., 2004. Ground-truthing the boron isotope paleo- $p$ H proxy in planktonic foraminifera shells: Partial dissolution and shell size effects. Paleoceanography 19. http://dx.doi.org/10.1029/2004PA001026.

Hönisch, B., Hemming, N.G., 2005. Surface ocean $\mathrm{pH}$ response to variations in $\mathrm{pCO}_{2}$ through two full glacial cycles. Earth and Planetary Science Letters 236 (1-2), 305-314.

Hönisch, B., et al., 2004. Assessing scleractinian corals as recorders for paleo-pH: empirical calibration and vital effects. Geochimica et Cosmochimica Acta 68 (18), 3675-3685.

Honisch, B., Hemming, N.G., Loose, B., 2007. Comment on "A critical evaluation of the boron isotope-pH proxy: the accuracy of ancient ocean $\mathrm{pH}$ estimates" by M. Pagani, D. Lemarchand, A. Spivack and J. Gaillardet. Geochimica et Cosmochimica Acta 71 (6), 1636-1641.

Honisch, B., Bickert, T., Hemming, N.G., 2008. Modern and Pleistocene boron isotope composition of the benthic foraminifer Cibicidoides wuellerstorfi. Earth and Planetary Science Letters 272 (1-2), 309-318.

Hönisch, B., Hemming, N.G., Archer, D., Siddall, M., McManus, J.F., 2009. Atmospheric carbon dioxide concentration across the Mid-Pleistocene transition. Science 324 (5934) 1551-1554.

Hut, G., 1987. Stable isotope reference samples for geochemical and hydrological investigations, Consultants Group Meeting. International Atomic Energy Agency (I.A.E.A.).

Joachimski, M.M., Simon, L., van Geldern, R., Lecuyer, C., 2005. Boron isotope geochemistry of Paleozoic brachiopod calcite: implications for a secular change in the boron isotope geochemistry of seawater over the Phanerozoic. Geochimica et Cosmochimica Acta 69 (16), 4035-4044

Kakihana, H., Kotaka, M., Satoh, S., Nomura, M., Okamoto, M., 1977. Fundamental studies on the ion-exchange of boron isotopes. Bulletin of the Chemical Society of Japan 50, $158-163$.

Klochko, K., Kaufman, A.J., Yao, W., Byrne, R.H., Tossell, J.A., 2006. Experimental measurement of boron isotope fractionation in seawater. Earth and Planetary Science Letters 248 (1-2), 261-270.

Korte, C., Kozur, H.W., Bruckshen, P., Veizer, J., 2003. Strontium isotope evolution of Late Permian and Triassic seawater. Geochimica et Cosmochimica Acta 67 (1), 47-62.

Korte, C., Jasper, T., Kozur, H.W., Veizer, J., 2005. $\mathrm{d}^{18} \mathrm{O}$ and $\mathrm{d}^{13} \mathrm{C}$ of Permian brachiopods: a record of seawater evolution and continental glaciation. Paleoceanography, Paleoclimatology, Paleoecology 224, 333-351.

Korte, C., Jones, P.J., Brand, U., Mertmann, D., Veizer, J., 2008. Oxygen isotope values from high-latitudes: clues for Permian sea-surfcae temperature gradients and Late Palaeozoic deglaciation. Palaeogeography, Palaeoclimatology, Palaeoecology 269, 1-16.

Krief, S., et al., 2010. Physiological and isotopic responses of scleractinian corals to ocean acidification. Geochimica et Cosmochimica Acta 74, 4988-5001.

Küster, H.C., 1844. Zoologische Notizen. Isis von Oken 9, 645-656.

Lécuyer, C., Grandjean, P., Reynard, B., Albarède, F., Telouk, P., 2002.11B/10B analysis of geological materials by ICP-MS Plasma 54: application to the boron fractionation between brachiopod calcite and seawater. Chemical Geology 186 (1-2), 45-55.
LeGrande, A.N., Schmidt, G.A., 2006. Global gridded data set of the oxygen isotopic composition in seawater. Geophysical Research Letters 33, 1-5.

Lemarchand, D., Gaillardet, J., Lewin, É., Allègre, C.J., 2000. The influence of rivers on marine boron isotopes and implications for reconstructing past ocean $\mathrm{pH}$. Nature 408, 951-954.

Lemarchand, D., Gaillardet, J., Lewin, E., Allegre, C.J., 2002. Boron isotope systematics in large rivers: implications for the marine boron budget and paleo-pH reconstruction over the Cenozoic. Chemical Geology 190 (1-4), 123-140.

Lepzelter, C.G., Anderson, T.F., Sandberg, P.A., 1983. Stable isotope variations in modern articulate brachiopods. American Association of Petroleum Geologists 67 (3), 500-501.

Mehrbach, C., Culberson, C.H., Hawley, J.E., Pytkowicz, R.M., 1973. Measurement of the apparent dissociation constants of carbonic acid in seawater at atmospheric pressure. Limnology and Oceanography 18, 897-907.

Millero, F.J., 1995. Thermodynamics of the carbon dioxide system in the oceans. Geochimica et Cosmochimica Acta 59 (4), 661-667.

Parkinson, D., Curry, G.B., Cusack, M., Fallick, A.E., 2005. Shell structure, patterns and trends of oxygen and carbon stable isotopes in modern brachiopod shells. Chemical Geology 219, 193-235.

Pearson, P.N., Palmer, M.R., 2000. Atmospheric carbon dioxide concentrations over the past 60 million years. Nature 406, 695-699.

Pérez-Huerta, A., et al., 2009. Brachiopod punctae: a complexity in shell biomineralisation. Journal of Structural Biology 167 (1), 62-67.

Pierrot, D., Lewis, E., Wallace, D.W.R., 2006. MS Excel Program Developed for CO2 System Calculations. Carbon Dioxide Information Analysis Center, Oak Ridge National Laboratory, U.S. Department of Energy, Oak Ridge, Tennessee.

Popp, B.N., Anderson, T.F., Sandberg, P.A., 1986. Brachiopods as indicators of original isotopic compositions in some Paleozoic limestones. Geological Society of America Bulletin 97 (10), 1262-1269.

Rae, J.W.B., Foster, G.L., Schmidt, D.N., Elliot, T., 2011. Boron isotopes and B/Ca in benthic foraminifera: proxies for the deep ocean carbonate system. Earth and Planetary Science Letters 302 (3-4), 403-413.

Reynaud, S., Hemming, N.G., Juillet-Leclerc, A., Gattuso, J.-P., 2004. Effect of $p \mathrm{CO}_{2}$ and temperature on the boron isotopic composition of a zooxanthellate coral: Acropora sp. Coral Reefs 23, 539-546.

Royer, D.L., et al., 2004. CO2 as a primary driver of Phanerozoic climate. GSA Today 14 (3), 4-10.

Russell, A.D., Hönisch, B., Spero, H.J., Lea, D.W., 2004. Effects of changes in seawater carbonate ion concentration and temperature on shell $\mathrm{U} / \mathrm{Ca}, \mathrm{Mg} / \mathrm{Ca}$, and $\mathrm{Sr} / \mathrm{Ca}$ of planktonic foraminifera. Geochimica et Cosmochimica Acta 68 (21), 4347-4361.

Rustad, J.R., Bylaska, E.J., Jackson, V.E., Dixon, D.A., 2010. Calculation of boron-isotope fractionation between $\mathrm{B}(\mathrm{OH}) 3(\mathrm{aq})$ and $\mathrm{B}(\mathrm{OH}) 4-(\mathrm{aq})$. Geochimica et Cosmochimica Acta 74 (10), 2843-2850.

Sanyal, A., et al., 1996. Oceanic $\mathrm{pH}$ control on the boron isotopic composition of foraminifera: evidence from culture experiments. Paleoceanography 11 (5), 513-517.

Sanyal, A., Nugent, M., Reeder, R.J., Bijma, J., 2000. Seawater $p H$ control on the boron isotopic composition of calcite: Evidence from inorganic calcite precipitation experiments. Geochimica et Cosmochimica Acta 64 (9), 1551-1555.

Sanyal, A., Bijma, J., Spero, H.J., Lea, D.W., 2001. Empirical relationship between $p H$ and the boron isotopic composition of G. sacculifer: implications for the boron isotope paleo- $p$ H proxy. Paleoceanography 16 (5), 515-519.

Schmahl, W.W., et al., 2004. The microstructure of the fibrous layer of terebratulide brachiopod shell calcite. European Journal of Mineralogy 16, 693-697.

Simon, L., Lecuyer, C., Marechal, C., Coltice, N., 2006. Modelling the geochemical cycle of boron: Implications for the long-term $\delta^{11} \mathrm{~B}$ evolution of seawater and oceanic crust. Chemical Geology 22 (1-2), 15.

Solander, in Dixon, G., 1789. A Voyage Around the World; But More Particularly to the North-West Coast of America: Performed in 1785, 1786, 1787, and 1788, in the King George and Queen Charlotte. Captains Portlock and Dixon.

Sowerby, G., 1846. Descriptions of thirteen new species of brachiopods. Proceedings of the Zoological Society of London, pp. 91-95.

Trotter, J., et al., 2011. Quantifying the pH 'vital effect' in the termperate zooxanthellate coral Cladocora caespotosa: validation of the boron seawater $\mathrm{pH}$ proxy. Earth and Planetary Science Letters 303, 163-173.

Williams, A., 1966. Growth and structure of the shell of living articulate bachiopods. Nature 211, 1146-1148

Williams, A., 1968. Evolution of the shell structure of articulate brachiopods. Special Papers in Palaentology. Palaeontological Association.

Williams, A., Brunton, H., Carlson, S., 1997. Treatise on Invertebrate Paleontology, Part H, Brachiopoda (Revised). vol. 1: Introduction. Geological Society of America and University of Kansas Press, Lawrence, pp. 1-539.

Yamamoto, K., Asami, R., Iryu, Y., 2010. Carbon and oxygen isotopic compositions of modern brachiopod shells from a warm-temperate shelf environment, Sagami Bay, central Japan. Palaeogeography, Palaeoclimatology, Palaeoecology 291, 348-359.

Zeebe, R.E., Wolf-Gladrow, D.A., 2001. $\mathrm{CO}_{2}$ in seawater: Equilibrium, kinetics, isotopes. Elsevier Oceanography Series, 65. Elsevier (346 pp.).

Zeebe, R.E., Sanyal, A., Ortiz, J.D., Wolf-Gladrow, D.A., 2001. A theoretical study of the kinetics of the boric acid-borate equilibrium in seawater. Marine Chemistry 1814 